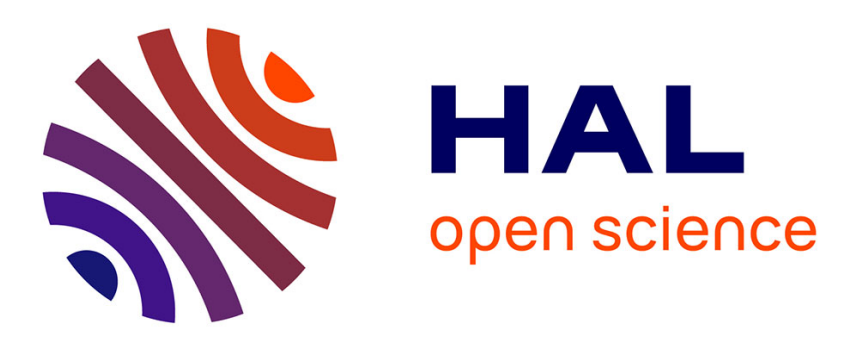

\title{
Dynamics of Single Pt Atoms on Alumina during CO Oxidation Monitored by Operando X-ray and Infrared Spectroscopies
}

C. Dessal, T. Len, F. Morfin, J. Rousset, M. Aouine, P. Afanasiev, L. Piccolo

\section{- To cite this version:}

C. Dessal, T. Len, F. Morfin, J. Rousset, M. Aouine, et al.. Dynamics of Single Pt Atoms on Alumina during CO Oxidation Monitored by Operando X-ray and Infrared Spectroscopies. ACS Catalysis, 2019, 9 (6), pp.5752-5759. 10.1021/acscatal.9b00903 . hal-02166659

\section{HAL Id: hal-02166659 \\ https://hal.science/hal-02166659}

Submitted on 15 May 2020

HAL is a multi-disciplinary open access archive for the deposit and dissemination of scientific research documents, whether they are published or not. The documents may come from teaching and research institutions in France or abroad, or from public or private research centers.
L'archive ouverte pluridisciplinaire HAL, est destinée au dépôt et à la diffusion de documents scientifiques de niveau recherche, publiés ou non, émanant des établissements d'enseignement et de recherche français ou étrangers, des laboratoires publics ou privés. 


\title{
Dynamics of single $\mathrm{Pt}$ atoms on alumina during $\mathrm{CO}$ oxidation moni- tored by operando X-ray and infrared spectroscopies
}

\author{
Caroline Dessal, Thomas Len, Franck Morfin, Jean-Luc Rousset, Mimoun Aouine, Pavel Afana- \\ siev, Laurent Piccolo*
}

Univ Lyon, Université Claude Bernard - Lyon 1, CNRS, IRCELYON - UMR 5256, 2 Avenue Albert Einstein, F-69626 VILLEURBANNE CEDEX, France.

\begin{abstract}
Single-atom catalysts (SACs) are promising atom-efficient materials, with potentially superior performances with respect to their nanoparticulate counterparts. Owing to its practical importance and relative simplicity, $\mathrm{CO}$ oxidation on $\mathrm{Pt} / \gamma-\mathrm{Al}_{2} \mathrm{O}_{3}$ is considered as an archetypal catalytic system. The efficiency of the corresponding SAC has recently been the subject of debate. In this work, in addition to systematic high-resolution scanning transmission electron microscopy, we have simultaneously monitored the Pt dispersion, oxidation state, and CO oxidation activity by operando fast X-ray absorption spectroscopy and diffuse reflectance infrared spectroscopy, both combined with mass spectrometry. It is shown that single $\mathrm{Pt}^{m+}$ atoms $(m \geq 2)$, resulting from the standard impregnation-calcination procedure of SAC preparation, are poorly active. However, they gradually but irreversibly convert into highly active $\sim 1$-nm-sized $\mathrm{Pt}^{\delta_{+}}$clusters $(\delta<2)$ throughout the heating/cooling reaction cycles, even under highly oxidizing conditions favorable to atomic dispersion. Increase in the Pt loading or the $\mathrm{CO} / \mathrm{O}_{2}$ concentration ratio accelerates the clustering-reduction phenomena. This work not only evidences a gradual aggregation/activation process for an important catalytic system, but also highlights the power of operando spectroscopies to address stability issues in single-atom catalysis.
\end{abstract}

\section{Keywords}

Single-atom catalysis; $\mathrm{Pt} / \gamma-\mathrm{Al}_{2} \mathrm{O}_{3}$; operando spectroscopies; XAS; DRIFTS

\section{INTRODUCTION}

In the quest for minimal consumption of precious metals, single-atom heterogeneous catalysis has recently attracted much attention because single-atom catalysts (SACs) expose all the virtually active metal atoms to the reactants. ${ }^{1-10}$ Moreover, with respect to supported nanoparticles, SACs can exhibit different performances in relation to their distinct electronic structure, onto which the support has a critical influence." These materials have shown promising performances in a number of reactions related to energy, environment and chemicals production. However, owing to the inherent tendency of single atoms to aggregate into larger entities such as nanoparticles, SAC stability may be the main issue in future developments. For example, several works have shown the agglomeration tendency of Pt atoms on various supports under reducing atmospheres. ${ }^{12-17}$ Nevertheless, whereas dynamical effects in catalysis have been investigated in detail for supported nanoparticles, ${ }^{18,19}$ similar studies on SACs are still scarce. Noticeably, in many studies published so far, the metal dispersion (single atom or cluster/nanoparticle) during, or even after the reaction, is unknown, making the in situ/operando approaches ${ }^{18,20-25}$ highly desirable. In this context, an atomic-scale understanding of SAC restructuring is expected to favor the design of stable SACs. ${ }^{26}$

A number of studies dedicated to $\mathrm{Pt} / \mathrm{Al}_{2} \mathrm{O}_{3}$ SACs have been reported to date, with applications to $\mathrm{CO}$ oxidation, water-gas shift, and hydrocarbon processing. ${ }^{27-32} \mathrm{CO}$ oxidation on $\mathrm{Pt} / \gamma-\mathrm{Al}_{2} \mathrm{O}_{3}$ can be considered as a reference model system due to its relative simplicity and practical relevance in e.g. air pollution control. ${ }^{33}$ In a pioneer work on $\mathrm{Pt}_{1} / \theta-\mathrm{Al}_{2} \mathrm{O}_{3}$, Narula and coworkers concluded from infrared/X-ray absorption spectroscopies and scanning transmission electron microscopy (STEM) that Pt single atoms are intrinsically active toward $\mathrm{CO}$ oxidation. ${ }^{30} \mathrm{~A}$ model based on density functional theory (DFT) suggested that $\mathrm{Pt}_{1}$ prefers to bond to $\mathrm{O}_{2}$ over $\mathrm{CO}$, and that the reaction proceeds through a Pt carbonate. In contrast, Stair and coworkers concluded from infrared spectroscopy, temperature-programmed reaction and STEM that, unlike Pt nanoparticles, single Pt atoms supported on a variety of substrates including $\gamma-\mathrm{Al}_{2} \mathrm{O}_{3}$, are inactive for $\mathrm{CO}$ oxidation and water-gas shift reactions. ${ }^{34}$ This was mostly ascribed to an excessively strong $\mathrm{Pt}_{1}-\mathrm{CO}$ interaction.

In a recent work, we have shown from environmental STEM, X-ray absorption spectroscopy and DFT investigations that single Pt atoms on alumina are stabilized in oxygen atmosphere through the formation of $\mathrm{Pt}-\mathrm{O}_{\text {ads }}-\mathrm{Al}_{\text {support }}$ 
bridges; in contrast, Pt atoms aggregate into mobile subnanometric clusters under hydrogen. ${ }^{17}$ Here, we investigate the structural stability of $\mathrm{Pt} / \gamma-\mathrm{Al}_{2} \mathrm{O}_{3}$ SACs throughout $\mathrm{CO}$ oxidation in correlation with their catalytic performances by using, in combination with STEM, state-of-the-art operando spectroscopies. We evidence that, even for relatively low Pt amounts and a priori favorable reaction conditions, single Pt atoms are prone to aggregate into clusters, which are much more active and then dominate the $\mathrm{CO}$ oxidation kinetics. This implies that, in metal/oxide SAC studies, even a low fraction of clusters or nanoparticles should not be neglected, as they may represent, depending on the considered reaction, the actual active species.

\section{EXPERIMENTAL SECTION}

\section{Catalyst preparation}

$\gamma-\mathrm{Al}_{2} \mathrm{O}_{3}$ powders (Sasol Puralox SCFa-140, >97.0 $\% \mathrm{Al}_{2} \mathrm{O}_{3}$ ) were calcined in air at $600{ }^{\circ} \mathrm{C}$ for $3 \mathrm{~h}$ before use. For catalyst preparation by incipient wetness impregnation, 2.0 $\mathrm{g}$ of alumina was impregnated with $1.8 \mathrm{~mL}$ of an aqueous solution of $\mathrm{Pt}\left(\mathrm{NH}_{3}\right)_{4}\left(\mathrm{NO}_{3}\right)_{2}$ (Alfa Aesar, $>50 \mathrm{wt} \% \mathrm{Pt}$ ), dried in air at $60{ }^{\circ} \mathrm{C}$ for $5 \mathrm{~h}$, and calcined in air $(40 \mathrm{~mL} / \mathrm{min})$ at 300 ${ }^{\circ} \mathrm{C}$ for $2 \mathrm{~h}\left(2^{\circ} \mathrm{C} / \mathrm{min}\right.$ ramp). The Pt loadings of the $0.3 \mathrm{Pt}$ and ${ }_{1} \mathrm{Pt}$ samples were find equal to $0.31 \mathrm{wt} \%$ and $0.96 \mathrm{wt} \%$, respectively, by inductively coupled plasma - optical emission spectroscopy (ICP-OES, Horiba Jobin Yvon).

\section{Scanning transmission electron microscopy}

The STEM-HAADF experiments were performed with a FEI Titan ETEM G2 electron microscope, equipped with a Cs image aberration corrector and operated at $300 \mathrm{keV}$. The extraction voltage, camera length, acceptance angles, STEM resolution and probe current were $4500 \mathrm{~V}, 245 \mathrm{~mm}$, 29.2-146 ${ }^{\circ}$, $0.14 \mathrm{~nm}$ and <0.1 nA, respectively. For sample preparation, the powder was crushed and dispersed in ethanol through ultrasonication, dropped onto a holey carbon-coated 200 mesh $\mathrm{Cu}$ grid, and dried by a lamp. To avoid contamination during analysis and remove all residual carbon, the samples were Ar plasma-cleaned for $20 \mathrm{~s}$ (Plasma Prep 5, GaLa Instrumente). No filtering was applied on the STEM images.

\section{Operando X-ray absorption spectroscopy}

The local structure of Pt species was investigated by XAS in transmission mode on the ROCK beam line at the SOLEIL synchrotron. X-ray absorption spectra at the $\mathrm{L}_{3}$ edge of Pt were recorded. The powder samples were placed inside a pseudo plug-flow operando cell composed of a sample holder fitted into a heated block. 35 The cell was connected to a gas distribution system allowing for careful control of the gas flows at atmospheric pressure. In situ thermal treatments were applied from RT to $300{ }^{\circ} \mathrm{C}$ under air flow $\left(10^{5} \mathrm{~Pa}, 50 \mathrm{~mL} / \mathrm{min}, 4^{\circ} \mathrm{C} / \mathrm{min}\right)$ or $\mathrm{H}_{2}$ flow (10 $\mathrm{Pa}, 30$ $\left.\mathrm{mL} / \mathrm{min}, 5{ }^{\circ} \mathrm{C} / \mathrm{min}\right)$. Under the reaction mixture at atmospheric pressure (total flow rate $50 \mathrm{~mL} / \mathrm{min}$ ), the sample was heated at $2{ }^{\circ} \mathrm{C} / \mathrm{min}$ from RT to $300{ }^{\circ} \mathrm{C}$, and cooled down at the same rate. The gas mixture consisted of $\mathrm{CO}: \mathrm{O}_{2}: \mathrm{He}=$ $2: 10: 88 \%$ (COOX10 conditions) or $\mathrm{CO}: \mathrm{O}_{2}: \mathrm{He}=2: 2: 96 \%$ ( $\mathrm{COOX}_{2}$ conditions). The reactor was flushed for 10 minutes under He between the oxidative and the reductive treatments. Data merging and preliminary analysis were carried out using ATHENA software. ${ }^{36}$ EXAFS fitting was performed using VIPER program. 37 The fit was performed alternatively in $\mathrm{k}$ and $\mathrm{R}$ spaces. When in the $\mathrm{R}$ space, it was done in the (Im + Module) mode, mathematically equivalent to the $\mathrm{k}$-fit.

It should be noted that the error in Pt-Pt coordination number $(\mathrm{CN})$ determination by EXAFS is high for these low-loaded and highly dispersed systems, because of the overlap between the Pt-Pt features and wiggles of the Pt-O FT signals. Thus, in the presence of several Pt-O bonds per $\mathrm{Pt}$ atom, determining the presence of less than one $\mathrm{Pt}$ neighbor is at the limit of the EXAFS technique. The second neighbor peak with a distance slightly above $3 \AA$ is most probably due to the support $\mathrm{Al}$ atoms involved in the $\mathrm{Pt}-\mathrm{O}-\mathrm{Al}$ bonds. However, the high disorder of the Pt coordination environment makes it impossible to fit this contribution with an acceptable figure of merit.

Operando diffuse reflectance infrared Fourier transform spectroscopy

Operando infrared spectroscopy was performed using a Thermo Nicolet 6700 FTIR spectrophotometer equipped with a DRIFTS cell (Harrick HVC-DRP) and a high-sensitivity MCT detector. The cell, equipped with $\mathrm{CaF}_{2}$ windows, was connected to a gas handling system allowing in situ treatments with several gases at temperatures up to $500{ }^{\circ} \mathrm{C}$. About $30 \mathrm{mg}$ of the powder sample was placed in the cell sample holder. The sample was submitted to the following treatments or reactions at atmospheric pressure with a total flow rate of $25 \mathrm{~mL} / \mathrm{min}$ : (i) $20 \% \mathrm{O}_{2}$ in $\mathrm{He}, 2$ ${ }^{\circ} \mathrm{C} / \mathrm{min}, 350{ }^{\circ} \mathrm{C}, 2 \mathrm{~h}$; (ii) $2 \% \mathrm{CO}+2$ or $10 \% \mathrm{O}_{2}$ in He, 2 cycles; (iii) $\mathrm{H}_{2}, 2{ }^{\circ} \mathrm{C} / \mathrm{min}, 350^{\circ} \mathrm{C}, 2 \mathrm{~h}$; (iv) identical to (ii); (v) identical to (i); (vi) identical to (ii). The spectra were recorded in the $1000-4000 \mathrm{~cm}^{-1}$ range at a resolution of $2 \mathrm{~cm}^{-1}$ by accumulating 64 scans. The Omnic software (Thermo) was used for initial data processing. Temperature cycles were composed of ramps $\left(3{ }^{\circ} \mathrm{C} / \mathrm{min}\right)$ and plateaus $(20 \mathrm{~min}$, for DRIFTS acquisition) every $50^{\circ} \mathrm{C}$. The reported temperature corresponds to that of the powder sample surface after calibration with a pyrometer. The gases exiting the DRIFTS cell were continuously monitored with a mass spectrometer (Aspec QMS from SRA Instruments). The experiments were also performed with bare $\gamma-\mathrm{Al}_{2} \mathrm{O}_{3}$ in order to subtract the signal of gaseous $\mathrm{CO}$ from the DRIFTS spectra.

\section{Catalytic tests}

The catalytic properties in $\mathrm{CO}$ oxidation were evaluated under atmospheric pressure in a continuous-flow fixedbed reactor which consisted of a cylindrical glass tube (10 $\mathrm{mm}$ inner diameter) equipped with a sintered glass filter supporting the catalyst powder. The same quantity of $\mathrm{Pt}$ $(0.5 \mathrm{mg})$ was used in all tests. The reactor was placed in a ceramic furnace heated or cooled at $1^{\circ} \mathrm{C} / \mathrm{min}$ between 50 ${ }^{\circ} \mathrm{C}$ and $280{ }^{\circ} \mathrm{C}$. The catalyst temperature was recorded through a thermocouple immersed in the catalytic bed. By using mass-flow controllers, the gases were mixed ( $\mathrm{CO}: \mathrm{O}_{2}: \mathrm{He}=2: 10: 88 \%$ or $2: 2: 96 \%$ ) and flowed through the reactor at a total rate of $50 \mathrm{Nml} / \mathrm{min}$. The effluent gases 

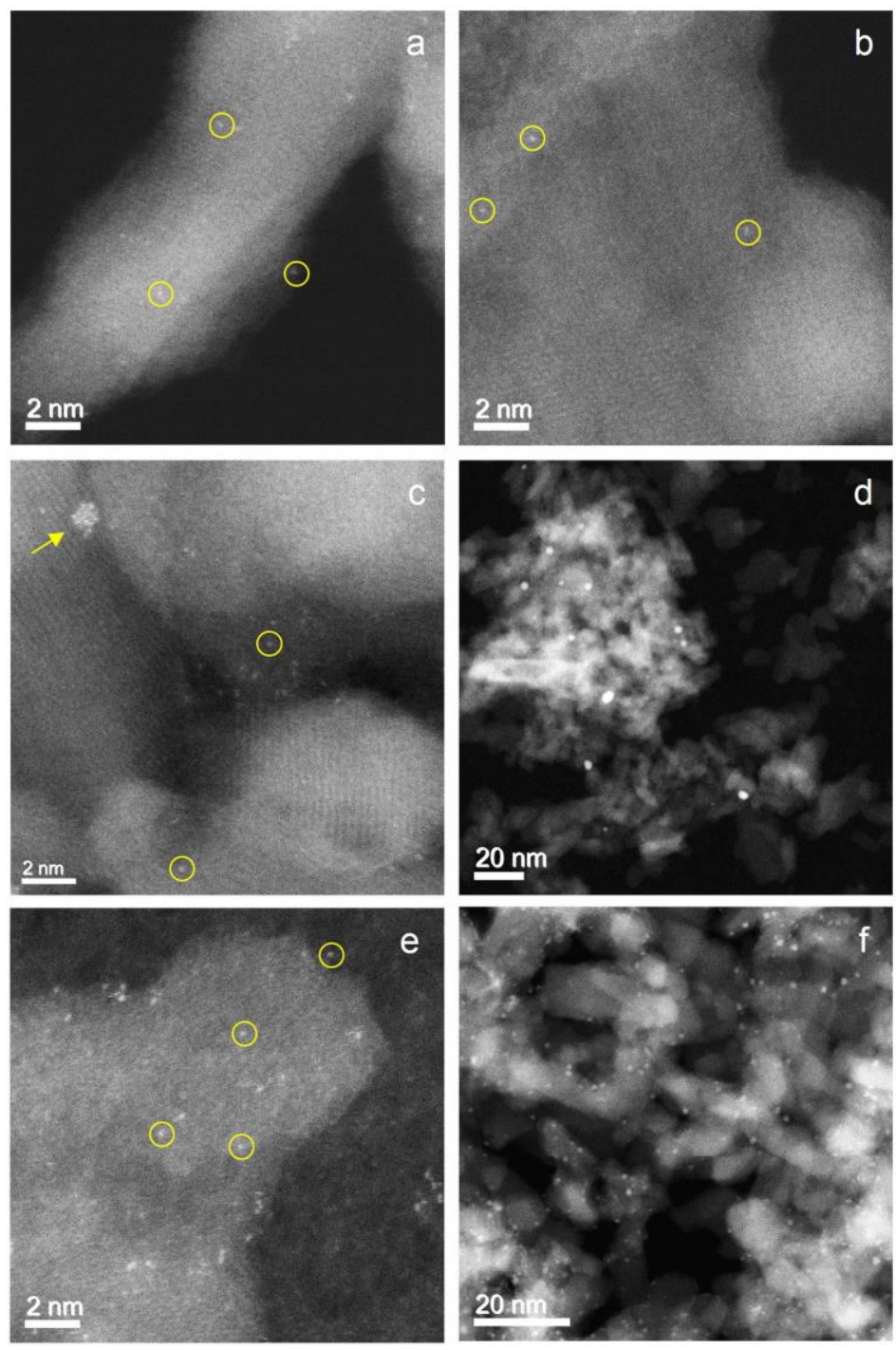

Figure 1. Representative STEM images of $\mathrm{Pt} / \gamma-\mathrm{Al}_{2} \mathrm{O}_{3}$ samples throughout the catalysis experiments. (a-c) o.3 wt $\% \mathrm{Pt} / \mathrm{Al}{ }_{2} \mathrm{O}_{3}$ catalyst after calcination (a), subsequent $\mathrm{CO}$ oxidation cycle with $\mathrm{CO}: \mathrm{O}_{2}=2: 10 \%$ (b), and after full experiment (c). Average size of the clusters (such as that pointed by the arrow) in (c): $1.0 \pm 0.3 \mathrm{~nm}$. (d) $0.3 \mathrm{wt} \% \mathrm{Pt} / \mathrm{Al}_{2} \mathrm{O}_{3}$ catalyst after full experiment with $\mathrm{CO}: \mathrm{O}_{2}=2: 2 \%$. Mostly Pt clusters are present (average size $1.9 \pm 1.0 \mathrm{~nm}$ ). (e-f) $1.0 \mathrm{wt} \% \mathrm{Pt}_{\mathrm{Al}} \mathrm{O}_{3}$ catalyst, as-prepared (e) and after full experiment with $\mathrm{CO}: \mathrm{O}_{2}=2: 10 \%$ (f). Mostly single Pt atoms are present in (e) and mostly Pt clusters (average size $1.0 \pm 0.2 \mathrm{~nm}$ ) are present in (f). Some of the single atoms are circled in yellow.

were analyzed online using a Micro GC equipped with a TCD detector.

\section{RESULTS AND DISCUSSION}

Two Pt $/ \gamma-\mathrm{Al}_{2} \mathrm{O}_{3}$ catalysts were investigated, with a $\mathrm{Pt}$ loading of $0.3 \mathrm{wt} \%$ (o.3Pt sample) or $1.0 \mathrm{wt} \%$ (1Pt sample). Fig. 1 and Figs. S1-S3 show STEM images of the samples. For the as-prepared (i.e., calcined) samples, while o.3Pt contains exclusively single Pt atoms (Fig. 1a), a mixture of single atoms and small clusters is present on $1 \mathrm{Pt}$ (Figs. 1e and S2a), consistently with previous reports. ${ }^{17,27}$

In order to compare the performances of these catalysts with those of pre-reduced ones, the samples were submitted to a series of successive reactive treatments under flow conditions at atmospheric pressure: (i) calcination in air, to accurately reset the initial (oxidized) conditions; (ii) $\mathrm{CO}$ oxidation reaction; (iii) reduction in hydrogen; (iv) $\mathrm{CO}$ oxidation (identical to ii). All four treatments were performed from RT up to $300{ }^{\circ} \mathrm{C}$, followed by cooling back to RT. For the reaction stages, two sets of conditions were used, with $\mathrm{CO}: \mathrm{O}_{2}$ contents in helium of $2: 10 \%$ (referred to as $\mathrm{COOX}_{10}$ conditions) or $2: 2 \%\left(\mathrm{COOX}_{2}\right)$. Note that the $\mathrm{COOX}_{10}$ (more oxidizing) conditions were chosen to tentatively stabilize the SAC, given that it is stable under oxygen. ${ }^{17}$ Similarly, pre-exposure to $\mathrm{O}_{2}$ was shown to limit the $\mathrm{H}_{2}$-induced sintering of $\mathrm{Pt}$ nanoparticles supported on alumina. ${ }^{38}$ This protocol was similarly applied in a conventional flow-fixed-bed catalytic reactor, in operando DRIFTS-MS experiments, and in synchrotron-based operando XAS-MS experiments. In conventional testing (Fig. 

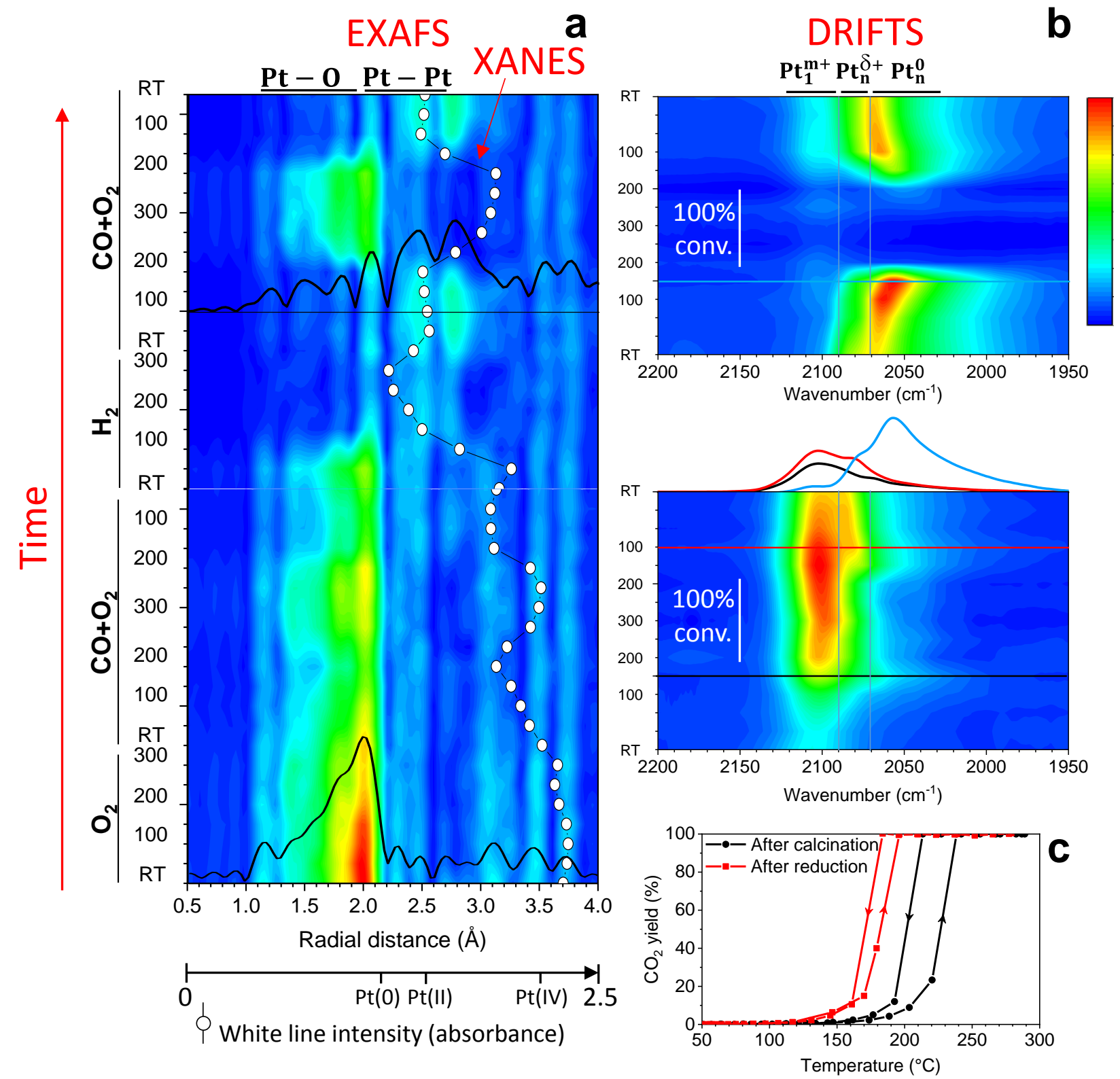

Figure 2. Monitoring of Pt species and their $\mathrm{CO}$ oxidation activity (o.3 wt $\left.\% \mathrm{Pt} / \gamma-\mathrm{Al}_{2} \mathrm{O}_{3}, \mathrm{CO}: \mathrm{O}_{2}=2: 10 \%\right)$. (a) EXAFS color map showing the evolution with time (from bottom to top) of the FT throughout the calcination/reaction/reduction/reaction procedure. The full color scale corresponds to $\mathbf{0 - 2 . 1 3} \AA^{-4}$ in FT module. Two FT signals are shown in classical view. The radial distance is phase-corrected. The white disks represent the XANES white line intensity in the same experiment. The intensity values for $\mathrm{Pt}, \mathrm{Pt}\left(\mathrm{NH}_{3}\right)_{4}\left(\mathrm{NO}_{3}\right)_{2}$ and $\mathrm{PtO}_{2}$ references (Fig. Sira) are reported on the bottom axis. (b) DRIFTS color map showing the evolution of the $v_{C-O}$ absorption band(s) in the Pt carbonyl wavenumber region during post-calcination (bottom panel) and post-reduction (top panel) reaction steps. The full color scales correspond to o-0.10 (bottom) and o-o.18 (top) in absorbance. Three spectra corresponding to the horizontal lines (at $150^{\circ} \mathrm{C}$ during heating and $100{ }^{\circ} \mathrm{C}$ during cooling) on the DRIFTS maps are plotted in classical view. The $100 \%$ CO conversion region, as derived from mass spectrometry, is indicated. In (a) and (b), the Y-axes show temperatures in ${ }^{\circ} \mathrm{C}$. (c) $\mathrm{CO}$ oxidation light off curves obtained in a conventional flow-fixed-bed reactor following a similar protocol as in operando experiments.

$\mathrm{S}_{4}$ ) and DRIFTS (Figs. $\mathrm{S}_{5}-\mathrm{S}_{7}$ ), two heating-cooling $\mathrm{CO}$ oxidation cycles (instead of one for XAS) were performed at each reaction stage in order to assess the catalyst stability.

Figure 2 displays the results of such an investigation for the $0.3 \mathrm{Pt}$ sample under oxygen-rich COOX 10 reaction conditions. In addition to Fig. $2 b$, a conventional view of the Pt-carbonyl region of DRIFTS spectra is shown in Fig. S8 (left panels). The corresponding data for $1 \mathrm{Pt}$ COOXıo (Fig. S9) and o.3Pt COOX2 (Fig. S1o) are reported in Supporting Information, together with XANES and EXAFS references (Fig. S11), and additional XAS raw data and analyses (Figs. S12-S15, Tables S1-S3). 


\section{Pre-oxidized single $P t$ atoms}

In the as-prepared (air-calcined) SAC, the EXAFS Fourier transform only shows a Pt-O contribution $(r \approx 2.0 \AA$, Fig. 2a) without any Pt-Pt one, confirming the absence of metallic Pt clusters, in accordance with previous works. ${ }^{17,30}$ Comparison of the XANES of the SAC with those of bulk Pt, bulk $\mathrm{PtO}_{2}$, and pure $\mathrm{Pt}\left(\mathrm{NH}_{3}\right)_{4}\left(\mathrm{NO}_{3}\right)_{2}$ precursor references (Fig. S11a) suggests an oxidation degree of the single $\mathrm{Pt}$ atoms comprised between II ( $\mathrm{Pt}$ precursor) and IV $\left(\mathrm{PtO}_{2}\right)$.

During the first CO oxidation cycle (bottom of Fig. 2a), the main EXAFS contribution remains the $\mathrm{Pt}-\mathrm{O}$ one. At first sight, the first $\mathrm{CO}$ oxidation run (heating) is performed on single Pt atoms, which show a moderate activity with a half-conversion temperature $T_{1 / 2} \approx 230{ }^{\circ} \mathrm{C}$ in a conventional flow-fixed-bed reactor (Figs. $2 \mathrm{c}$ and $\mathrm{S}_{4 \mathrm{a}}$ ). Upon cooling, $T_{1 / 2}$ decreases to $\mathrm{ca}$. $200{ }^{\circ} \mathrm{C}$. The resulting hysteresis is mainly explained in the literature by mass or heat diffusion effects, low-temperature poisoning of Pt by $\mathrm{CO}$, and different oxidation states of $\mathrm{Pt}$ in light-off and extinction stages, which can be coupled to each other.33,39,40 Looking closely at the EXAFS evolution, small Pt-Pt features are visible at $150-200{ }^{\circ} \mathrm{C}$ during heating. Then, the Pt-Pt feature becomes more clearly visible during cooling, in the $150{ }^{\circ} \mathrm{C}$ $\mathrm{RT}$ temperature region. The presence of Pt-Pt features is correlated to minima in the XANES white line intensity (WLI), represented horizontally in Fig. 2a. The Pt-Pt feature appearance in EXAFS and WLI decrease in XANES indicate Pt clustering and reduction.

Another indication of Pt clustering comes from DRIFTS monitoring (Figs. $2 \mathrm{~b}$ and S8). While the main peak at 2106$2100 \mathrm{~cm}^{-1}$ is ascribed to CO linearly adsorbed on single $\mathrm{Pt}^{\mathrm{m+}}$ cations $(m \geq 2)$, the shoulder at $2090-2070 \mathrm{~cm}^{-1}$, present at ca. $150{ }^{\circ} \mathrm{C}$ on heating and at $150-50{ }^{\circ} \mathrm{C}$ on cooling, can be ascribed to partially oxidized Pt clusters $\left(\mathrm{Pt}^{\delta+}, \delta<2\right) .34,39$ Unlike the main band, this shoulder shifts towards higher wavenumbers as temperature decreases, due to the increased dipole-dipole coupling between $\mathrm{CO}$ adsorbates. ${ }^{41}$ Furthermore, the disappearance of this contribution -and this contribution only- throughout the full $\mathrm{CO}$ conversion period suggests that the precursor of the active species is $\mathrm{Pt}^{\delta_{+}}$. This small fraction of Pt clusters would coexist with poorly active single Pt cations, the DRIFTS signature of which appears indeed essentially unaffected by the reaction. Indeed, no decrease of the $\mathrm{Pt}^{\mathrm{m+}}-\mathrm{CO}$ band intensity was observed at high $\mathrm{CO}$ conversion (Fig. 2b). However, a slight decrease in this single-atom contribution was observed at high $\mathrm{CO}$ conversion in the second $\mathrm{CO}$ oxidation cycle (Fig. $\mathrm{S}_{5}$ ), and more markedly under oxygen-poor $\mathrm{COOX}_{2}$ conditions (Fig. S7). In these cases the Pt clusters are majority species, and the decreasing amounts of SAs could be expected. Nevertheless, unlike the $\mathrm{Pt}^{\delta_{+}}-\mathrm{CO}$ (clusters), the $\mathrm{Pt}^{m+}-\mathrm{CO}$ species (SAs) never disappear completely, thus the depletions can be ascribed to desorption and not necessarily to reaction. Further, the $\sim 2100 \mathrm{~cm}^{-1}$ band (SAs) actually increases on heating, and decreases back at the end of the cycle (Fig. 2b). Such an evolution indicates that single Pt atoms can hardly accommodate both $\mathrm{CO}$ and oxygen and that the adsorption competition is favorable to oxygen at low temperature and to $\mathrm{CO}$ at higher temperatures, at which the reaction proceeds on the clusters. This partly reconciles the results of Moses DeBusk et al. and Ding et al., who found that single Pt atoms prefer to accommodate oxygen or $\mathrm{CO}$, respectively. ${ }^{30,34}$ Pt clustering appears even more marked during the second DRIFTS cycle (Fig. S5), and it correlates with a higher activity (lower $T_{1 / 2}$, Fig. S4a). However, at the end of the CO oxidation cycles, a large proportion of single Pt atoms remains, consistently with STEM analyses (Fig. 1b).

Remarkably, some authors have proposed, using DFT calculations, $\mathrm{CO}$ oxidation mechanisms on $\mathrm{Pt} / \mathrm{Al}_{2} \mathrm{O}_{3}(\mathrm{olo})$ SACs, which involve either $\mathrm{Pt}\left(\mathrm{CO}_{3}\right)^{30}$ or Pt $(\mathrm{O}-\mathrm{O}-\mathrm{C}=\mathrm{O})^{42}$ species. The former has also been considered by Newton et al. to interpret their transient experiments on commercial $\mathrm{Pt} / \mathrm{Al}_{2} \mathrm{O}_{3}$ catalysts. ${ }^{43,44}$ Our simultaneous monitoring of the catalyst state and light-off activity, based for the first time on operando experiments, shows that the involvement of Pt carbonates is not required (though not ruled out) to explain our data. In our conditions, the oxidation of $\mathrm{CO}$ to $\mathrm{CO}_{2}$ can proceed through the conventional Langmuir-Hinshelwood mechanism over the fraction of $\mathrm{Pt}$ clusters formed in situ within the initial SAC. The increase of this cluster fraction throughout $\mathrm{CO}$ oxidation cycles leads to an increase in the $\mathrm{CO}$ oxidation activity. Our results are consistent with those of Ding et al.34 and of Lou and Liu, ${ }^{45}$ who concluded on the inactivity or poor activity, respectively, of $\mathrm{Pt}$ single atoms supported on $\gamma-\mathrm{Al}_{2} \mathrm{O}_{3}$, In connection to these findings, the superiority of subnanometric clusters overs single atoms was previously reported for $\mathrm{CO}$ oxidation over $\mathrm{Ir} / \mathrm{FeO}_{\mathrm{x}} \cdot{ }^{46}$

\section{Pre-reduced Pt clusters}

The second part of the experiments consisted in a reducing treatment in hydrogen in order to obtain a majority of Pt clusters, ${ }^{17}$ followed by an additional $\mathrm{CO}$ oxidation cycle (or two in the cases of DRIFTS and conventional tests). Fig.2a shows the gradual disappearance of the Pt-O EXAFS feature during the hydrogen treatment, together with the decrease in the XANES WLI and the appearance of a small Pt-Pt contribution $(r \approx 2.6 \AA)$. As previously reported, such a treatment of a Pt $/ \gamma-\mathrm{Al}_{2} \mathrm{O}_{3} \mathrm{SAC}$ leads to a dominant fraction of $0.9 \mathrm{~nm}$-sized Pt clusters ${ }^{13,17}$ (see also Fig. S2c,d for ${ }_{1}$ Pt sample). The Pt-Pt CN was close to 6 (Table S1), in agreement with the calculations of Jentys for 13-atom spherical clusters. ${ }^{47}$ The Pt-Pt $\mathrm{CN}$ remains roughly constant under $\mathrm{CO} / \mathrm{O}_{2}$ at low temperature, up to $150{ }^{\circ} \mathrm{C}$, i.e. before the light-off. DRIFTS supports the quasi exclusive presence of reduced Pt clusters in these conditions, as attested by the $2070-2050 \mathrm{~cm}^{-1}$ feature corresponding to linear $\mathrm{Pt}^{\mathrm{o}}-\mathrm{CO}$ adsorption, with clear coverage-dependent band shift. ${ }^{8}$ A fraction of partially oxidized Pt also exists (shoulder at ca. $2080 \mathrm{~cm}^{-1}$, better seen in Fig. S8), which is assigned to $\mathrm{Pt}^{\delta_{+}}$multimers and/or cluster periphery sites. The sudden disappearance of the $2070-2050 \mathrm{~cm}^{-1}$ DRIFTS feature upon light-off (Fig. 2 b and S8) shows again that the Pt clusters -now majority- are the catalytically active species. This pre-reduced catalyst is much more active than the pre-calcined one, with a decrease of $T_{1 / 2}$ by $52{ }^{\circ} \mathrm{C}$ (Figs. 
$2 \mathrm{c}$ and $\mathrm{S}_{4}$ ). The amplification of activity is ascribed to the increased fraction of Pt clusters. The level of the XANES WLI under reaction conditions (Fig. 2a) suggests that these active Pt clusters are oxidized.

However, no Pt-Pt contribution is present in the EXAFS signal during the $100 \% \mathrm{CO}$ conversion period, while the $\mathrm{Pt}$ O component $(r \approx 2.0 \AA$ ) and the WLI are reinforced (Fig. 2a). This is ascribed to the oxidation of the Pt clusters into amorphous $\mathrm{PtO}_{\mathrm{x}}$. Indeed, when $100 \% \mathrm{CO}$ conversion is achieved, in the major part of the catalyst bed, the gaseous atmosphere contains only inert gas and $\mathrm{O}_{2}$, thus being highly oxidative. In order to confirm this hypothesis, as opposed to an oxidative redispersion of the Pt clusters into single Pt cations, a quenching experiment was carried out during conventional catalytic tests (on the ${ }_{1} \mathrm{Pt}$ sample, which shows a similar behavior as $0.3 \mathrm{Pt}$, see Fig. S9). At the end of the COOX1o heating ramp, after a plateau of $25 \mathrm{~min}$ at $280^{\circ} \mathrm{C}$, the reactor was quickly water-cooled to RT under air and the sample was analyzed by STEM. Fig. S2e,f clearly shows Pt clusters with an average size of $1.1 \pm 0.3 \mathrm{~nm}$, which supports the hypothesis that the Pt clusters are not redispersed but oxidized during the reaction at high temperature, i.e. at $100 \%$ CO conversion.

Upon return to low temperature under $\mathrm{CO}$ oxidation conditions, the reinforcement of the DRIFTS feature at ca. $2100 \mathrm{~cm}^{-1}$ (Figs. $2 \mathrm{~b}$ and S8, top panels), which had appeared at $150^{\circ} \mathrm{C}$ upon heating, is most likely due to $\mathrm{CO}$ adsorption on remaining single $\mathrm{Pt}^{m+}$ cations. Although present in much smaller fraction after reduction, these species behave similarly as before reduction towards $\mathrm{CO}$ adsorption. Indeed, as previously mentioned, an increase of the 2100$2110 \mathrm{~cm}^{-1}$ feature (single Pt cations after calcination) upon heating up to $300{ }^{\circ} \mathrm{C}$ and subsequent cooling down to 150 ${ }^{\circ} \mathrm{C}$ was observed (Figs. 2 b and S8, bottom panels).

However, most of the signal $\left(2080-2050 \mathrm{~cm}^{-1}\right)$ is ascribable to Pt clusters. Unlike before the reduction treatment (cycles 1 and 2), after reduction two successive $\mathrm{CO}$ oxidation cycles produce similar DRIFTS signals (Fig. $\mathrm{S}_{5}$, cycles 3 and 4 ), consistently with the catalytic tests (Fig. S4). This indicates that the clustering process is complete. At the end of the whole process, Pt is thus mostly returned into the form of $\mathrm{Pt}^{\circ}$ and, to lower extent, $\mathrm{Pt}^{\delta_{+}}$clusters (low XANES intensity and $\mathrm{CN}=6$, see Table $\mathrm{S} 1$ ). However, a significant proportion of single $\mathrm{Pt}$ atoms $\left(\mathrm{Pt}^{m+}\right)$ remains, as seen from EXAFS and DRIFTS (Fig. 2a) and post-reaction STEM (Figs. 1c and Sid-f). In DRIFTS experiments, after the first two stages (post-calcination and post-reduction), the catalyst was further calcined in situ under air flow and two additional CO oxidation cycles ( 5 and 6 , Fig. S5) were performed. The DRIFTS data overall appear very similar to those of the post-reduction stage. This implies that the clustering process, which begins after the initial calcination, and completes after reduction, is irreversible.

\section{Effect of Pt loading and reaction conditions}

When comparing the results for $0.3 \mathrm{Pt} \mathrm{COOX} 10$ (Fig. 2) with those for 1 Pt COOX10 (Fig. S9) and o.3Pt COOX2 (Fig.
S10), all three processes look qualitatively similar. However, DRIFTS evidences that the fraction of metallic Pt clusters in the first reaction stage is more important at higher Pt loading (1Pt COOX10), and even more under less oxidizing conditions (0.3Pt $\mathrm{COOX}_{2}$ ). Consistently with the above conclusion that Pt clusters are more active than single atoms, $T_{1 / 2}$ is decreased by $24{ }^{\circ} \mathrm{C}$ at higher Pt loading under COOX10 conditions (Fig. $\mathrm{S}_{4}$ ). In contrast, after the reduction treatment leading to a majority of Pt clusters in all cases, the DRIFTS data are almost identical for $0.3 \mathrm{Pt}$ and ${ }_{1} \mathrm{Pt}$, and accordingly the COOX10 activities are now similar. The activity of $0.3 \mathrm{Pt}$ is lower under $\mathrm{COOX}_{2}$ conditions $\left(T_{1 / 2}\right.$ $=239{ }^{\circ} \mathrm{C}$, vs. $226{ }^{\circ} \mathrm{C}$ for COOX10) because of the limited supply in $\mathrm{O}_{2}$ induced by strong $\mathrm{CO}$ adsorption at low temperature, i.e. negative reaction order in $\mathrm{CO}$, similarly to what is known for larger Pt particles within the LangmuirHinshelwood mechanism. ${ }^{49}$ In all the cases, as shown by Figs. $\mathrm{S}_{5}-\mathrm{S}_{7}$ (cycles 3-6 vs cycles 1-2), the adsorption of $\mathrm{CO}$ as measured by DRIFTS is much more prominent on prereduced catalysts (Pt clusters) than on pre-oxidized ones (single Pt atoms).

Fig. 3 summarizes the results and allows a quantitative comparison of the evolutions of the white line intensities (a) and Pt-Pt coordination numbers (b) between the three cases. Both show large variations throughout the experiment. The WLI is maximum under highly oxidizing conditions, i.e. calcination treatment and high reaction temperature (high CO conversion). It decreases under less oxidizing conditions, i.e. reduction treatment and low reaction temperature. The WLI decrease corresponds to concomitant decrease of Pt-O CNs in EXAFS, from more than 5 to less than 1 (Fig. S12 and Tables $\mathrm{S}_{1}-\mathrm{S}_{3}$ ). As expected, the WLI and the Pt-O CN show very similar trends (Fig. S12). Overall, Fig. 3 evidences clear Pt reduction (a) and Pt clustering (b) tendencies. Switching from 0.3Pt-COOX10 conditions to ${ }_{1} \mathrm{Pt}-\mathrm{COOX}_{1}$ or $0 .{ }_{3} \mathrm{Pt}-\mathrm{COOX}_{2}$ leads to a decrease in the WLI, i.e. both the increase in Pt loading and the decrease in oxygen concentration have Pt reduction effects. The PtPt bonds corresponding to few-atom clusters are already detected in EXAFS from $\sim 100{ }^{\circ} \mathrm{C}$ upon heating in $1 \mathrm{Pt}$ $\mathrm{COOX}_{10}$ and $0.3 \mathrm{Pt}-\mathrm{COOX}_{2}$ experiments, whereas for $0.3 \mathrm{Pt}-\mathrm{COOX} 10$ the Pt clusters appear only below $200{ }^{\circ} \mathrm{C}$ on cooling. However, the $\mathrm{COOX}_{2}$ conditions induce a larger increase in $\mathrm{CN}$ in the first reaction cooling stage, with a maximum $\mathrm{CN}$ of 5 vs. 3-4 for the COOX 10 conditions. Therefore, more reducing ( $\left.\mathrm{COOX}_{2}\right)$ conditions lead to a larger number of $\mathrm{Pt}$ atoms in the clusters. 


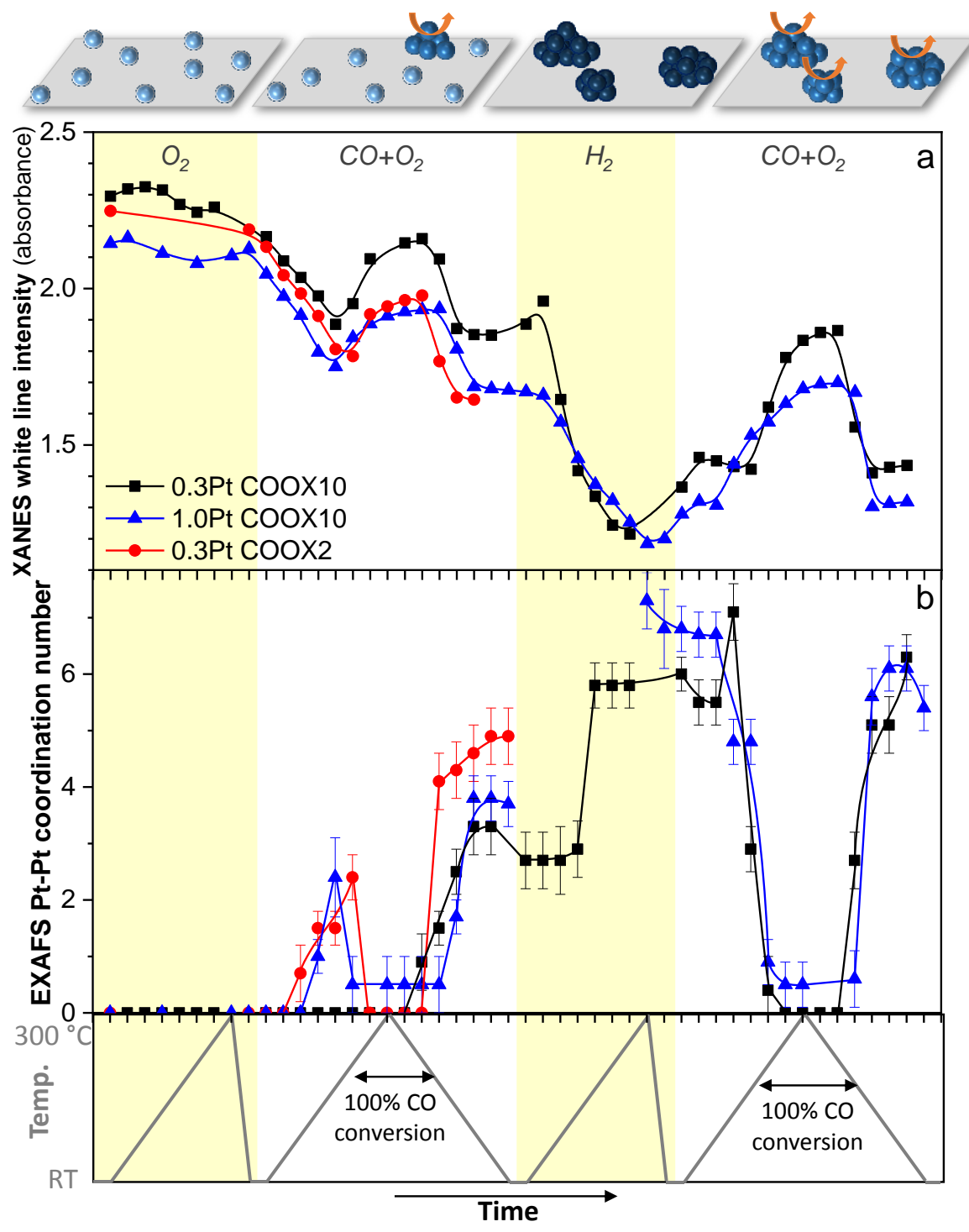

Figure 3. Evolution of XANES white line intensities (a) and Pt-Pt coordination numbers derived from EXAFS analysis (b) during the calcination/reaction/reduction/reaction sequence on $0.3 \mathrm{wt} \% \mathrm{Pt} / \gamma-\mathrm{Al}_{2} \mathrm{O}_{3}$ (COOXı and COOX2 conditions) and 1.0 $w t \% \mathrm{Pt} / \gamma-\mathrm{Al}_{2} \mathrm{O}_{3}(\mathrm{COOX} 10)$. The total duration of each experiment was $\sim 20 \mathrm{~h}$, except in COOX2 for which only the first half was carried out. The drawings represent the catalyst state. The ball color represents the oxidation state of Pt, going from highly cationic (light blue) to slightly cationic (medium blue) and reduced (dark blue). Orange arrows represent CO oxidation. The double black arrows at the bottom of the figure indicate the approximate full-CO-conversion temperature regions.

\section{CONCLUSIONS}

In this work, in addition to conventional catalytic testing and STEM, we have used operando XAS and DRIFTS spectroscopies to investigate the oxidation of $\mathrm{CO}$ over a $0.3 \mathrm{wt} \%$ $\mathrm{Pt} / \gamma^{-} \mathrm{Al}_{2} \mathrm{O}_{3} \mathrm{SAC}$ prepared by incipient wetness impregnation-calcination. The SAC behavior has been compare $\mathrm{d}$ to its pre-reduced and $1 \mathrm{w}$ t\% counter parts under both standard $\left(\mathrm{CO}: \mathrm{O}_{2}=2: 2 \mathrm{wt} \%\right)$ and highly oxidizing $\left(\mathrm{CO}: \mathrm{O}_{2}=\right.$ 2:10 wt\%) conditions.

It is shown that the initially single Pt cations gradually aggregate into partially oxidized Pt clusters in the course of the reaction light-off/light-out cycles. The single atoms are strongly coordinated to oxygen at room temperature, and to $\mathrm{CO}$ at higher temperature. Such a strong adsorption prevents the SAs from catalyzing the reaction. As the clusters are more active than the single atoms, their formation during the reaction, and upon hydrogen treatment, leads to increases in the $\mathrm{CO}$ oxidation activity. As compared to the low-loaded SAC, the $1 \mathrm{wt} \% \mathrm{Pt}$ catalyst shows a larger proportion of clusters, a lower average oxidation state, and a higher Pt-specific activity. Similarly, exposing the SAC to less oxidizing conditions deeply increases the cluster fraction and decreases the oxidation state.

While demonstrating the clustering dynamics of Pt atoms from a systematic multi-technique investigation, this work enriches the debate on the $\mathrm{CO}$ oxidation activity of 
$\mathrm{Pt}_{1} / \mathrm{Y}-\mathrm{Al}_{2} \mathrm{O}_{3} \mathrm{SACs}$. These results are likely to be qualitatively applicable to other catalytic systems and demonstrate the value of operando investigations to assess the intrinsic activity-stability of SACs.

\section{ASSOCIATED CONTENT}

Supporting Information. Additional STEM, DRIFTS, XAS, and $\mathrm{CO}$ oxidation data.

This material is available free of charge via the Internet at http://pubs.acs.org.

\section{AUTHOR INFORMATION}

\section{Corresponding Author}

* E-mail: Laurent.Piccolo@ircelyon.univ-lyonı.fr

\section{Notes}

The authors declare no competing financial interests.

\section{ACKNOWLEDGMENT}

S. Belin (SOLEIL), C. Zlotea and A. Malouche (ICMPE) are acknowledged for support with XAS experiments at the ROCK beamline of SOLEIL synchrotron (proposal 20170160). L. Roiban (MATEIS) is acknowledged for help in TEM experiments. N. Cristin and P. Mascunan (IRCELYON) are acknowledged for ICP analyses. Agence Nationale de la Recherche (UltraCat project, ANR-17-CEo6-ooo8), Région Auvergne-Rhône Alpes (CMIRA 2016 project) and LABEX iMUST ANR-10LABX-o064/ ANR-11-IDEX-ooo7 are acknowledged for financial support. The XAS work was supported by a public grant overseen by the French National Research Agency (ANR) as part of the "Investissements d'Avenir" program (ANR-10EQPX 45). CLYM is acknowledged for access to the FEI Titan microscope.

\section{REFERENCES AND NOTES}

(1) Qiao, B.; Wang, A.; Yang, X.; Allard, L. F.; Jiang, Z.; Cui, Y.; Liu, J.; Li, J.; Zhang, T. Single-Atom Catalysis of CO Oxidation Using $\mathrm{Pt}_{1} / \mathrm{FeO}_{x}$. Nat. Chem. 2011, 3 (8), 634-641. https://doi.org/10.1038/nchem.1095.

(2) Li, Z.-Y.; Yuan, Z.; Li, X.-N.; Zhao, Y.-X.; He, S.-G. CO Oxidation Catalyzed by Single Gold Atoms Supported on Aluminum Oxide Clusters. J. Am. Chem. Soc. 2014, 136 (40), 14307-14313. https://doi.org/10.1021/ja508547z.

(3) Wei, H.; Liu, X.; Wang, A.; Zhang, L.; Qiao, B.; Yang, X.; Huang, Y.; Miao, S.; Liu, J.; Zhang, T. $\mathrm{FeO}_{\mathrm{x}}$-Supported Platinum Single-Atom and Pseudo-Single-Atom Catalysts for Chemoselective Hydrogenation of Functionalized Nitroarenes. Nat. Commun. 2014, 5, 5634. https://doi.org/10.1038/ncomms6634.

(4) Yan, H.; Cheng, H.; Yi, H.; Lin, Y.; Yao, T.; Wang, C.; Li, J.; Wei, S.; Lu, J. Single-Atom Pd $\mathrm{Pd}_{1}$ Graphene Catalyst Achieved by Atomic Layer Deposition: Remarkable Performance in Selective Hydrogenation of 1,3-Butadiene. J. Am. Chem. Soc. 2015, 137 (33), 10484-10487. https://doi.org/10.1021/jacs.5b06485.

(5) Jones, J.; Xiong, H.; DeLaRiva, A. T.; Peterson, E. J.; Pham, H.; Challa, S. R.; Qi, G.; Oh, S.; Wiebenga, M. H.; Pereira Hernandez, X. I.; et al. Thermally Stable Single-Atom Platinum-on-Ceria Catalysts via Atom Trapping. Science 2016, 353 (6295), 150-154. https://doi.org/10.1126/science.aaf8800.

(6) Caparrós, F. J.; Soler, L.; Rossell, M. D.; Angurell, I.; Piccolo, L.; Rossell, O.; Llorca, J. Remarkable Carbon Dioxide Hydrogenation to Ethanol on a Palladium/Iron Oxide Single-
Atom Catalyst. ChemCatChem 2018, 10 (11), 2365-2369. https://doi.org/10.1002/cctc.201800362.

Liu, J. Catalysis by Supported Single Metal Atoms. $A C S C a-$ tal. 2017, 7, 34-59. https://doi.org/10.1021/acscatal.6b01534.

Wang, A.; Li, J.; Zhang, T. Heterogeneous Single-Atom Catalysis. Nat. Rev. Chem. 2018, 2 (6), 65-81. https://doi.org/10.1038/s41570-018-0010-1.

cui, X.; Li, W.; Ryabchuk, P.; Junge, K.; Beller, M. Bridging Homogeneous and Heterogeneous Catalysis by Heterogeneous Single-Metal-Site Catalysts. Nat. Catal. 2018, 1 (6), 385-397. https://doi.org/10.1038/s41929-018-0090-9.

(10) Lang, R.; Xi, W.; Liu, J.-C.; Cui, Y.-T.; Li, T.; Lee, A. F.; Chen, F.; Chen, Y.; Li, L.; Li, L.; et al. Non Defect-Stabilized Thermally Stable Single-Atom Catalyst. Nat. Commun. 2019, 10 (1), 234. https://doi.org/10.1038/s41467-01808136-3.

(11) Chen, Y.; Huang, Z.; Ma, Z.; Chen, J.; Tang, X. Fabrication, Characterization, and Stability of Supported Single-Atom Catalysts. Catal. Sci. Technol. 2017, 7 (19), 4250-4258. https://doi.org/10.1039/C7CY00723J.

(12) Bradley, S. A.; Sinkler, W.; Blom, D. A.; Bigelow, W.; Voyles, P. M.; Allard, L. F. Behavior of Pt Atoms on Oxide Supports During Reduction Treatments at Elevated Temperatures, Characterized by Aberration Corrected Stem Imaging. Catal. Lett. 2012, 142 (2), 176-182. https://doi.org/10.1007/s10562-011-0756-2.

(13) Sinkler, W.; Sanchez, S. I.; Bradley, S. A.; Wen, J.; Mishra, B.; Kelly, S. D.; Bare, S. R. Aberration-Corrected Transmission Electron Microscopy and in Situ XAFS Structural Characterization of $\mathrm{Pt} / \gamma-\mathrm{Al}_{2} \mathrm{O}_{3}$ Nanoparticles. ChemCatChem 2015, 7 (22), 3779-3787. https://doi.org/10.1002/cctc.201500784.

(14) Nagai, Y.; Dohmae, K.; Ikeda, Y.; Takagi, N.; Tanabe, T.; Hara, N.; Guilera, G.; Pascarelli, S.; Newton, M. A.; Kuno, O.; et al. In Situ Redispersion of Platinum Autoexhaust Catalysts: An On-Line Approach to Increasing Catalyst Lifetimes? Angew. Chem. Int. Ed. 2008, 47 (48), 9303-9306. https://doi.org/10.1002/anie.200803126.

(15) Gänzler, A. M.; Casapu, M.; Vernoux, P.; Loridant, S.; Cadete Santos Aires, F. J.; Epicier, T.; Betz, B.; Hoyer, R.; Grunwaldt, J.-D. Tuning the Structure of Platinum Particles on Ceria In Situ for Enhancing the Catalytic Performance of Exhaust Gas Catalysts. Angew. Chem. Int. Ed. 2017, 56 (42), 13078-13082. https://doi.org/10.1002/anie.201707842.

(16) Duan, S.; Wang, R.; Liu, J. Stability Investigation of a High Number Density $\mathrm{Pt}_{1} / \mathrm{Fe}_{2} \mathrm{O}_{3}$ Single-Atom Catalyst under Different Gas Environments by HAADF-STEM. Nanotechnol. 2018, 29 (20), 204002. https://doi.org/10.1088/13616528/aab1d2.

(17) Dessal, C.; Sangnier, A.; Chizallet, C.; Dujardin, C.; Morfin, F.; Rousset, J.-L.; Aouine, M.; Bugnet, M.; Afanasiev, P.; Piccolo, L. Atmosphere-Dependent Stability and Mobility of Catalytic Pt Single Atoms and Clusters on $\gamma-\mathrm{Al}_{2} \mathrm{O}_{3} . \mathrm{Na}$ noscale 2019, 11 (14), 6897-6904. https://doi.org/10.1039/ C9NR01641D.

(18) Lira, E.; Merte, L. R.; Behafarid, F.; Ono, L. K.; Zhang, L.; Roldan Cuenya, B. Role and Evolution of Nanoparticle Structure and Chemical State during the Oxidation of $\mathrm{NO}$ over Size- and Shape-Controlled $\mathrm{Pt} / \gamma-\mathrm{Al}_{2} \mathrm{O}_{3}$ Catalysts under Operando Conditions. ACS Catal. 2014, 4 (6), 1875-1884. https://doi.org/10.1021/cs500137r.

(19) Zhai, H.; Alexandrova, A. N. Fluxionality of Catalytic Clusters: When It Matters and How to Address It. ACS Catal. 2017, 7 (3), 1905-1911. https://doi.org/10.1021/acscatal.6b03243.

(20) Frenken, J.; Groot, I. Operando Research in Heterogeneous Catalysis, 1st ed. 2017.; Springer International Publishing AG: New York, NY, 2017.

(21) Kaftan, A.; Kollhoff, F.; Nguyen, T.-S.; Piccolo, L.; Laurin, M.; Libuda, J. Sensitivity of CO Oxidation toward Metal 
Oxidation State in Ceria-Supported Catalysts: An Operando DRIFTS-MS Study. Catal. Sci. Technol. 2016, 6 (3), 818828. https://doi.org/10.1039/C5CY00827A.

(22) Zlotea, C.; Oumellal, Y.; Provost, K.; Morfin, F.; Piccolo, L. Role of Hydrogen Absorption in Supported Pd Nanocatalysts during CO-PROX: Insights from Operando X-Ray Absorption Spectroscopy. Appl. Catal. B 2018, 237, 1059-1065. https://doi.org/10.1016/j.apcatb.2018.06.059.

(23) Asakura, H.; Hosokawa, S.; Ina, T.; Kato, K.; Nitta, K.; Uera, K.; Uruga, T.; Miura, H.; Shishido, T.; Ohyama, J.; et al. Dynamic Behavior of Rh Species in Rh/Al2O3 Model Catalyst during Three-Way Catalytic Reaction: An Operando X-Ray Absorption Spectroscopy Study. J. Am. Chem. Soc. 2018, 140 (1), 176-184.

https://doi.org/10.1021/jacs.7b07114.

(24) Zhang, S.; Tang, Y.; Nguyen, L.; Zhao, Y.-F.; Wu, Z.; Goh, T.-W.; Liu, J. J.; Li, Y.; Zhu, T.; Huang, W.; et al. Catalysis on Singly Dispersed Rh Atoms Anchored on an Inert Support. ACS Catal. 2018, 8 (1), 110-121.

https://doi.org/10.1021/acscatal.7b01788.

(25) Liu, L.; Zakharov, D. N.; Arenal, R.; Concepcion, P.; Stach, E. A.; Corma, A. Evolution and Stabilization of Subnanometric Metal Species in Confined Space by in Situ TEM. Nat. Commun. 2018, 9 (1), 574.

https://doi.org/10.1038/s41467-018-03012-6.

(26) Qin, R.; Liu, P.; Fu, G.; Zheng, N. Strategies for Stabilizing Atomically Dispersed Metal Catalysts. Small Methods 2018, 2 (1), 1700286. https://doi.org/10.1002/smtd.201700286.

(27) Kwak, J. H.; Hu, J.; Mei, D.; Yi, C.-W.; Kim, D. H.; Peden, C. H. F.; Allard, L. F.; Szanyi, J. Coordinatively Unsaturated $\mathrm{Al}^{3+}$ Centers as Binding Sites for Active Catalyst Phases of Platinum on $\gamma-\mathrm{Al}_{2} \mathrm{O}_{3}$. Science 2009, 325 (5948), 1670-1673. https://doi.org/10.1126/science.1176745.

(28) Mei, D.; Kwak, J. H.; Hu, J.; Cho, S. J.; Szanyi, J.; Allard, L. F.; Peden, C. H. F. Unique Role of Anchoring Penta-Coordinated $\mathrm{Al}^{3+}$ Sites in the Sintering of $\gamma-\mathrm{Al}_{2} \mathrm{O}_{3}$-Supported $\mathrm{Pt}$ Catalysts. J. Phys. Chem. Lett. 2010, 1 (18), 2688-2691. https://doi.org/10.1021/jz101073p.

(29) Zhai, Y.; Pierre, D.; Si, R.; Deng, W.; Ferrin, P.; Nilekar, A. U.; Peng, G.; Herron, J. A.; Bell, D. C.; Saltsburg, H.; et al. Alkali-Stabilized Pt-OHx Species Catalyze Low-Temperature Water-Gas Shift Reactions. Science 2010, 329 (5999), 1633-1636. https://doi.org/10.1126/science.1192449.

(30) Moses-DeBusk, M.; Yoon, M.; Allard, L. F.; Mullins, D. R.; Wu, Z.; Yang, X.; Veith, G.; Stocks, G. M.; Narula, C. K. CO Oxidation on Supported Single Pt Atoms: Experimental and $\mathrm{Ab}$ Initio Density Functional Studies of CO Interaction with Pt Atom on $\theta-\mathrm{Al}_{2} \mathrm{O}_{3}(010)$ Surface. J. Am. Chem. Soc. 2013, 135 (34), 12634-12645.

https://doi.org/10.1021/ja401847c.

(31) Zhang, Z.; Zhu, Y.; Asakura, H.; Zhang, B.; Zhang, J.; Zhou, M.; Han, Y.; Tanaka, T.; Wang, A.; Zhang, T.; et al. Thermally Stable Single Atom $\mathrm{Pt} / \mathrm{m}-\mathrm{Al}_{2} \mathrm{O}_{3}$ for Selective Hydrogenation and CO Oxidation. Nat. Commun. 2017, 8, 16100. https://doi.org/10.1038/ncomms16100.

(32) Cui, X.; Junge, K.; Dai, X.; Kreyenschulte, C.; Pohl, M.-M.; Wohlrab, S.; Shi, F.; Brückner, A.; Beller, M. Synthesis of Single Atom Based Heterogeneous Platinum Catalysts: High Selectivity and Activity for Hydrosilylation Reactions. $A C S$ Cent. Sci. 2017, 3 (6), 580-585.

https://doi.org/10.1021/acscentsci.7b00105.

(33) Morfin, F.; Nguyen, T.-S.; Rousset, J.-L.; Piccolo, L. Synergy between Hydrogen and Ceria in Pt-Catalyzed CO Oxidation: An Investigation on $\mathrm{Pt}-\mathrm{CeO} 2$ Catalysts Synthesized by Solution Combustion. Appl. Catal. B 2016, 197, 2-13. https://doi.org/10.1016/j.apcatb.2016.01.056.

(34) Ding, K.; Gulec, A.; Johnson, A. M.; Schweitzer, N. M.; Stucky, G. D.; Marks, L. D.; Stair, P. C. Identification of Active Sites in CO Oxidation and Water-Gas Shift over Supported Pt Catalysts. Science 2015, 350 (6257), 189-192. https://doi.org/10.1126/science.aac6368.
La Fontaine, C.; Barthe, L.; Rochet, A.; Briois, V. X-Ray Absorption Spectroscopy and Heterogeneous Catalysis: Performances at the SOLEIL's SAMBA Beamline. Catal. Today 2013, 205, 148-158. https://doi.org/10.1016/j.cattod.2012.09.032.

(36) Ankudinov, A. L.; Ravel, B.; Rehr, J. J.; Conradson, S. D. Real-Space Multiple-Scattering Calculation and Interpretation of x-Ray-Absorption near-Edge Structure. Phys. Rev. B 1998, 58 (12), 7565-7576.

https://doi.org/10.1103/PhysRevB.58.7565.

(37) Klementev, K. V. Extraction of the Fine Structure from XRay Absorption Spectra. J. Phys. D: Appl. Phys. 2001, 34 (2), 209. https://doi.org/10.1088/0022-3727/34/2/309.

(38) Matos, J.; Ono, L. K.; Behafarid, F.; Croy, J. R.; Mostafa, S.; DeLaRiva, A. T.; Datye, A. K.; Frenkel, A. I.; Roldan Cuenya, B. In Situ Coarsening Study of Inverse Micelle-Prepared Pt Nanoparticles Supported on $\gamma-\mathrm{Al}_{2} \mathrm{O}_{3}$ : Pretreatment and Environmental Effects. Phys. Chem. Chem. Phys. 2012, 14 (32), 11457-11467.

https://doi.org/10.1039/C2CP41339F.

Carlsson, P.-A.; Österlund, L.; Thormählen, P.; Palmqvist, A.; Fridell, E.; Jansson, J.; Skoglundh, M. A Transient in Situ FTIR and XANES Study of CO Oxidation over $\mathrm{Pt} / \mathrm{Al}_{2} \mathrm{O}_{3}$ Catalysts. J. Catal. 2004, 226 (2), 422-434. https://doi.org/10.1016/j.jcat.2004.06.009.

(40) Casapu, M.; Fischer, A.; Gänzler, A. M.; Popescu, R.; Crone, M.; Gerthsen, D.; Türk, M.; Grunwaldt, J.-D. Origin of the Normal and Inverse Hysteresis Behavior during CO Oxidation over $\mathrm{Pt} / \mathrm{Al}_{2} \mathrm{O}_{3}$. ACS Catal. 2017, 7 (1), 343-355. https://doi.org/10.1021/acscatal.6b02709.

(41) Primet, M. Electronic Transfer and Ligand Effects in the Infrared Spectra of Adsorbed Carbon Monoxide. J. Catal. 1984, 88 (2), 273-282. https://doi.org/10.1016/00219517(84)90003-4.

(42) Gao, H. CO Oxidation Mechanism on the $\gamma$-A12O3 Supported Single Pt Atom: First Principle Study. Appl. Surf. Sci. 2016, 379, 347-357. https://doi.org/10.1016/j.apsusc.2016.04.009.

(43) Newton, M. A.; Ferri, D.; Smolentsev, G.; Marchionni, V.; Nachtegaal, M. Room-Temperature Carbon Monoxide Oxidation by Oxygen over $\mathrm{Pt} / \mathrm{Al}_{2} \mathrm{O}_{3}$ Mediated by Reactive Platinum Carbonates. Nat. Commun. 2015, 6, 8675.

https://doi.org/10.1038/ncomms9675.

(44) Newton, M. A.; Ferri, D.; Smolentsev, G.; Marchionni, V.; Nachtegaal, M. Kinetic Studies of the Pt Carbonate-Mediated, Room-Temperature Oxidation of Carbon Monoxide by Oxygen over Pt $/ \mathrm{Al}_{2} \mathrm{O}_{3}$ Using Combined, Time-Resolved XAFS, DRIFTS, and Mass Spectrometry. J. Am. Chem. Soc. 2016, 138 (42), 13930-13940. https://doi.org/10.1021/jacs.6b06819.

(45) Lou, Y.; Liu, J. CO Oxidation on Metal Oxide Supported Single Pt Atoms: The Role of the Support. Ind. Eng. Chem. Res. 2017, 56 (24), 6916-6925. https://doi.org/10.1021/acs.iecr.7b01477.

(46) Lin, J.; Chen, Y.; Zhou, Y.; Lin, L.; Qiao, B.; Wang, A.; Liu, J.; Wang, X.; Zhang, T. More Active Ir Subnanometer Clusters than Single-Atoms for Catalytic Oxidation of $\mathrm{CO}$ at Low Temperature. AIChE J. 2017, 63, 4003-4012. https://doi.org/10.1002/aic.15756.

(47) Jentys, A. Estimation of Mean Size and Shape of Small Metal Particles by EXAFS. Phys. Chem. Chem. Phys. 1999, 1 (17), 4059-4063. https://doi.org/10.1039/A904654B.

(48) Alexeev, O. S.; Chin, S. Y.; Engelhard, M. H.; Ortiz-Soto, L.; Amiridis, M. D. Effects of Reduction Temperature and Metal-Support Interactions on the Catalytic Activity of Pt/ $\gamma$ $\mathrm{Al}_{2} \mathrm{O}_{3}$ and $\mathrm{Pt} / \mathrm{TiO}_{2}$ for the Oxidation of $\mathrm{CO}$ in the Presence and Absence of $\mathrm{H}_{2}$. J. Phys. Chem. B 2005, 109 (49), 2343023443. https://doi.org/10.1021/jp054888v.

(49) Engel, T.; Ertl, G. Elementary Steps in the Catalytic Oxidation of Carbon Monoxide on Platinum Metals. Adv. Catal. 1979, $28,1-78$. 


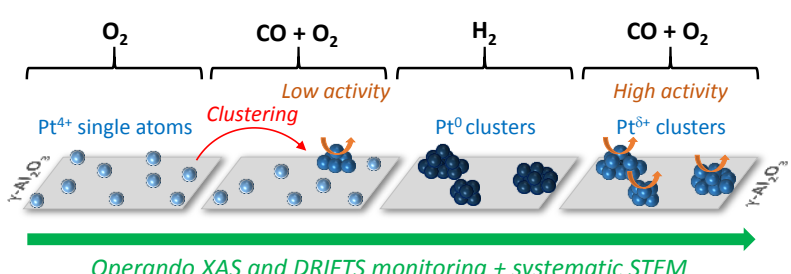

Operando XAS and DRIFTS monitoring + systematic STEM 